\title{
First record of Borrelia burgdorferi sensu lato antibodies in stray dogs in the Northwest Region of Parana State, Brazil
}

\section{Primeira detecção de anticorpos Anti-Borrelia burgdorferi Sensu Lato em cães errantes da região Noroeste do Estado do Paraná, Brasil}

\author{
Daniela Dib Gonçalves ${ }^{1 *}$; Rodrigo Assunção Moura ${ }^{1}$; Márcia Kuster de Paula Dreer ${ }^{1}$; \\ Denise do Amaral Gomes Nascimento ${ }^{2}$; Graziela Vendrame Rodrigues ${ }^{1}$; \\ Isabel Cristina da Silva Caetano; ${ }^{1}$ Odilon Vidotto ${ }^{3}$; Julio Cesar de Freitas 3 ; \\ Maria Luísa Vieira ${ }^{4}$
}

\begin{abstract}
The aim of this study was to determine the occurrence of B. burgdorferi sensu lato s.l. antibodies in stray dogs of the urban area of Umuarama Town, localized in the northwest region of Parana state, Brazil. Serum samples from 168 dogs were tested using indirect immunofluorescence assay (IFA) and Western Blot (WB) in order to detect anti-Borrelia burgdorferi s.l. antibodies. The IFI analysis was used as screening test and positive results were confirmed employing the WB technique. Sixty-five $(38.69 \%)$ of 168 serum samples were positive in the IFI; 54 of them $(83.07 \%)$ were confirmed by the WB. The overall data analysis confirmed the presence of anti-B. burgdorferi s.l. antibodies in $32.14 \%$ (54/168) dogs, what suggests that northwest region of Parana State may constitute a risk area for Lyme disease. Further studies are necessary to determine the epidemiological characteristics of this disease in the region studied.
\end{abstract}

Key words: Borreliosis, canids, diagnostic, IFA, western blot

\section{Resumo}

O objetivo deste estudo foi determinar a ocorrência de anticorpos anti-B. burgdorferi sensu lato sl em cães errantes da área urbana da cidade de Umuarama, localizado na região noroeste do estado do Paraná, Brasil. Amostras de soro de 168 cães foram testados utilizando imunofluorescência indireta (IFI) e Western Blot (WB), a fim de detectar anticorpos anti-Borrelia burgdorferi sl. A IFI foi utilizada como teste de triagem e os resultados positivos foram confirmados empregando a técnica de WB. Sessenta e cinco $(38,69 \%)$ de 168 amostras de soro foram positivas na IFI; 54 deles $(83,07 \%)$ foram confirmados pela WB. A análise geral dos dados confirmaram a presença de anticorpos anti-B. burgdorferi sl em

\footnotetext{
${ }^{1}$ Discentes de Doutorado, Dept ${ }^{\circ}$ de Medicina Veterinária Preventiva, Universidade Paranaense, UNIPAR, Umuarama, PR, Brasil. E-mail: danieladib@unipar.br; marciakuster@unipar.br; rodrigomoura81@me.com; grazielavr@hotmail.com; belcaetano@ hotmail.com

${ }^{2}$ Discente de Mestrado do Programa de Pós-Graduação em Ciência Animal da UEL, Londrina, PR, Brasil. nascimentodag@ gmail.com

3 Profs. Drs., Dept ${ }^{\mathrm{o}}$ de Medicina Veterinária Preventiva, DMVP, Universidade Estadual de Londrina, UEL, Londrina, PR, Brasil. E-mail: vidotto@uel.br; freitasj@uel.br

${ }^{4}$ Grupo de Leptospirose e Borreliose, Unidade de Microbiologia Médica, Global Health and Tropical Medicine, GHTM, Instituto de Higiene e Medicina Tropical, Universidade Nova de Lisboa, Lisboa, Portugal. E-mail: vieira@ihmt.unl.pt

* Autor for correspondence
} 
32,14\% (54/168) dos cães, o que sugere que a região noroeste do Estado do Paraná, pode constituir uma área de risco para a doença de Lyme. Mais estudos são necessários para determinar as características epidemiológicas da doença na região estudada.

Palavras-chave: Borreliose, canídeos, diagnóstico, imunofluorescencia indireta, western blot

\section{Introduction}

Lyme Borreliosis (LB) is a tick-borne disease caused by spirochetes of Borrelia burgdorferi sensu lato complex s.1., which undertake different animal species and humans (DANTAS-TORRES, 2008; STEERE, 1997). In Brazil, the LB is known as Brazilian Lyme-Like or Baggio-Yoshinari Syndrome due many aspects, including clinical symptoms, differ from the disease found in the northern hemisphere (YOSHINARI et al., 2010).

In Europe, North America and other continents, the spirochetes are transmitted by ticks from Ixodes genus (BARROS-BATTESTI et al., 2000; YPARRAGUIRRE et al., 2007). In Brazil, some studies have indicated the presence of $B$. burgdorferi s.l. in ticks from other genera such as Amblyomma, Rhipicephalus and Dermacentor (GONÇALVES et al., 2013b; MANTOVANI et al., 2012; YOSHINARI et al., 2010). Among these vectors, ticks belonging to Ixodes genus seem to be involved in the sylvatic transmission cycle of disease, whereas ticks from Amblyomma genus are associated to transmission between domestic animals and humans (ABEL et al., 2000; SOARES et al., 2000; YOSHINARI et al., 2003).

Epidemiological studies in different regions of Brazil, involving domestic animals have demonstrated the presence of anti-Borrelia spp. antibodies in cattle, buffalos, equines, dogs and humans (CORREA et al., 2012; DANTASTORRES, 2008; JOPPERT et al., 2001).

Particularly, among dogs, this disease constitutes an important vector-borne disease, since the infection is usually asymptomatic and there is no correlation between seropositivity and sex, age and/or animal health condition (DANTAS-TORRES, 2008). When symptomatic this disease can cause arthropathy, fever, lethargy and lack of appetite. In some cases it may also induce kidneys and heart impairment (DANTAS-TORRES, 2008; LITTMAN et al., 2006; MANTOVANI et al., 2007). The prevalence of antiBorrelia spp. antibodies in dogs is high in Brazil, varying from $9,0 \%$ to $83.9 \%$, according to previous studies in different regions of the country (ALVES et al., 2004; CORREIA et al., 2012; JOPPERT et al., 2001; O'DWYER et al., 2004; SOARES et al., 2000). All these studies showed a close relationship between the ticks' infestation and high antibody rates against Lyme spirochetes.

Epidemiological surveillance studies in Europe have associated the presence of anti-B. burgdorferi s.l. antibodies in dogs as a good indication of the exposure of their owners and/or handlers to infected ticks, since they frequently share the same indoor and outdoor areas (MEAD et al., 2011; SMITH et al., 2012). In Brazil, cases of Brazilian LymeLike disease or Baggio-Yoshinari Syndrome were detected in humans and dogs by indirect immunofluorescence assay (IFA) and/or Enzymelinked Immunosorbent Assay ELISA in different regions. However, few studies were conducted using Western Blot (WB) to confirm the presence of B. burgdorferi s.l. infection, as recommended by the Center for Diseases Control and Prevention (CDC) (ALVES et al., 2004; CARRANZATAMAYO et al., 2012; DANTAS-TORRES, 2008; GONÇALVES et al., 2013a; JOPPERT et al., 2001; YOSHINARI et al., 2010). The aim of this study was to determine, by indirect immunofluorescence (IFI) and western blot (WB), the presence of anti- $B$. burgdorferi s.l. antibodies in stray dogs of the urban area of Umuarama Town, Parana state, Brazil. 


\section{Material and Methods}

The town of Umuarama is located in the northwest region of Parana state, Brazil. On the outskirts of the city, there is a private, philanthropic shelter maintained by staff and visitors, it collects stray dogs around the city and forwards them for adoption. At the shelter, the animals are allocated in collective kennels regardless of breed, gender, age or size, and those that are debilitated or presenting suspicion of any infectious disease are kept in individual kennels, isolated from the other animals.

The study included 168 dogs regardless of age, gender or race, which lived in the shelter for the period March-May 2011. At the time of blood collection no animal showed any clinical signs of borreliosis, and all of them were infested by ticks. It was not possible to obtain information on the origin, exact age and sanitary status of these dogs, since the animals were found wandering in the streets of the Umuarama town (PR) at the time they were taken to the shelter.

Up to $10 \mathrm{~mL}$ of blood from each dog was collected by veterinarians via jugular venipuncture. Blood samples were identified and forwarded to the Laboratory of Preventive Veterinary Medicine of Paranaense University (UNIPAR) to obtain serum. Each sample was divided into two aliquots and stored in sterile flasks, identified and kept at $-20^{\circ} \mathrm{C}$ until to completion diagnostic tests. Serological tests were performed at the Protozoology Laboratory of Preventive Veterinary Medicine Department of Londrina State University (UEL).

Serum samples were screened for antibodies against $B$. burgdorferi s.l. by indirect immunofluorescence assay (IFA); glass slides coated with immobilized spirochetes (antigen) from the reference strain (B31) of B. burgdorferi sensu stricto (s.s.) were used (COLLARES-PEREIRA et al., 2000). These slides were prepared by the
Group of Lyme Borreliosis from the Institute of Tropical Medicine, Universidade Nova de Lisboa, Portugal. Sera presenting Borrelia with titers $\geq 64$ were considered positive. Sera from dogs without borreliosis were used as negative control. The results were subsequently confirmed by Western Blot (WB) using the following commercial kit "recomBlot Borrelia canis IgG" (Mikrogen $\AA$, Germany). Highly purified recombinant $B$. burgdorferi s.s., $B$. afzelii and $B$. garinii antigens were used in the WB procedure. And in the WB, the results of antigenic fractions (p100, VlsE, p58, p41, p39, OspA, OspC $B$. garinii, OspC of B. burgdorferi s.s, OspC of $B$. afzelli, OspC B. garinii2, p41/i B. garinii, p41/i B. afzelli and $\mathrm{P} 18$ ) were performed according to the manufacturer's instructions.

Regarding ticks, identification of taxa (genus and species) was performed using dichotomous keys based on Brazilian Ixodidae fauna (ARAGÃO et al., 1961; BARROS-BATTESTI et al., 2000).

This study was approved by the Ethics Committee for Animal Experiments (CEPEEA) of the University of Parana (UNIPAR) under process number 20677/2011.

\section{Results and Discussion}

Blood samples from 168 dogs of indeterminate breed, including 29 males and 139 females, aged between six months and 13 years were collected. All dogs $(100 \%)$ showed ticks fixed on their body and all were identified as Rhipicephalus sanguineus.

In IFA analysis, 38.69\% (65/168) samples were considered reactive showing titers of 1:64, 1:128 and 1:256 (Table 1). The IFA analysis was used as screening test and reactive samples were confirmed employing the WB technique (Figure 1). Among the 65 reactive sera by IFA, $54(83.07 \%)$ were positive in $\mathrm{WB}$, confirming the presence of anti- $B$. burgdorferi s.l. antibodies. The Figure 1 shows WB positive reaction for some samples. 
Table 1. Frequency of antibody titers found in indirect immunofluorescence assay (IFA) for Borrelia burgdorferi s.l. in 168 serum samples from stray dogs housed in a private shelter in the northwest region of Parana State, Brazil, 2011.

\begin{tabular}{lccc}
\hline \multirow{2}{*}{ Titers of Antibodies } & \multicolumn{2}{c}{ Frequency } & \multirow{2}{*}{ Total (\%) } \\
\cline { 2 - 3 } & Female & Male & $37(56.92 \%)$ \\
64 & 28 & 09 & $19(29.23 \%)$ \\
128 & 19 & - & $09(13.85 \%)$ \\
\hline Total & 08 & 01 & $65(100 \%)$ \\
\hline
\end{tabular}

Figure 1. Western blot (WB) positive results for Borrelia burgdorferi s.l in serum samples from stray dog in Brazil, 2011. Each trip indicates the quantitative value corresponding to the sum of the reactive antigenic fractions.

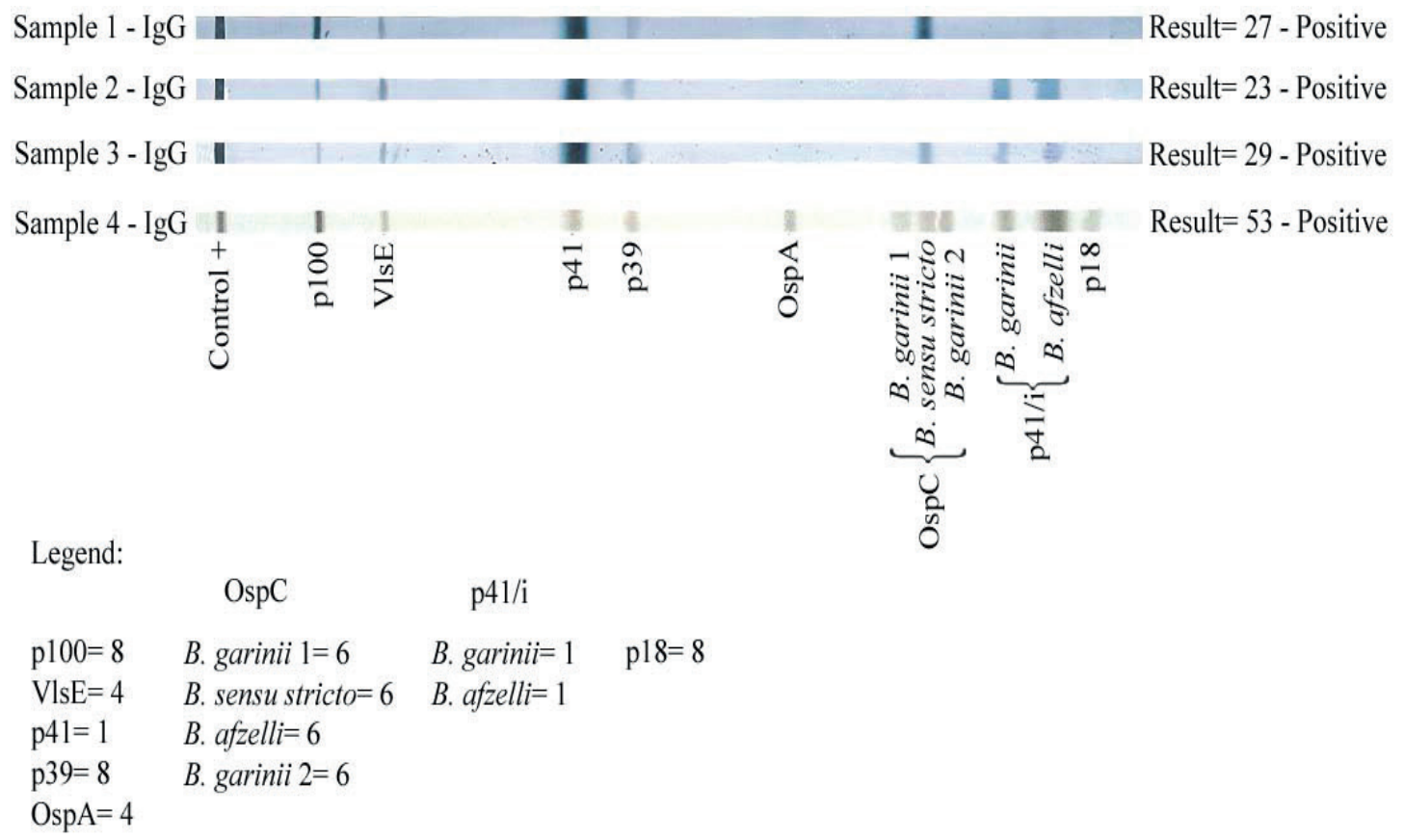

The overall data analysis confirmed the results among male and female dogs obtained by presence of B. burgdorferi s.1. in 32.14\% (54/168) IFI analysis and confirmed by WB test.

dogs. The Table 2 shows the frequency of positive

Table 2. Shows the frequency of positive strains in Indirect Immunofluorescence Assay (IFA) and Western Blot (WB) analysis among male and female dogs housed in a private shelter in the northwest region of Parana State, Brazil, 2011.

\begin{tabular}{lcc}
\hline \multirow{2}{*}{ Gender } & \multicolumn{2}{c}{ Frequency of Antibodies } \\
\cline { 2 - 3 } & Indirect Immunofluorescence Assay (IFA) & Western Blot (WB) \\
\hline Female & $55(84.61 \%)$ & $47(87.04 \%)$ \\
Male & $10(15.38 \%)$ & $7(12.96 \%)$ \\
\hline Total & $65(100 \%)$ & $54(100 \%)$ \\
\hline
\end{tabular}


Due to close contact, dogs have an important role in the maintenance and transmission of zoonotic disease agents to humans, including $B$. burgdorferi $\mathrm{s}$.1. This situation constitutes a serious public health concern, especially regarding stray dogs, since they are considered an important reservoir for borreliosis, with spirochetes being isolated from health dogs (BURGESS, 1986; DANTAS-TORRES, 2008; MERINO et al., 2000).

This is the first report to confirm the presence of B. burgdorferi s.l. antibodies by IFA and WB in stray dogs at the northwest region of Paraná State, Brazil. The IFA analysis of serum samples for antiBorrelia spp. antibodies showed 38.69\% (65/168) of reactivity, corroborating the prevalence found in other studies published in Brazil and Europe (CORDEIRO et al., 2012; DANTAS-TORRES, 2008; SOARES et al., 1999).

In Brazil, the presence of antibodies against Borrelia spp. has been studied in different animal species at Rio de Janeiro (RJ), São Paulo (SP) and Pará (PA) states and these studies have shown prevalences, ranging from $9.7 \%$ to $83.91 \%$ using different sorological methodologies (ALVES et al., 2004; CORDEIRO et al., 2012; CORREA et al., 2012; JOPPERT et al., 2001; SOARES et al., 1999). It is important to emphasize that among dogs, the frequency of these antibodies has doubled in the last 14 years in the Rio de Janeiro state (SOARES et al., 2000; ALVES et al., 2004; CORDEIRO et al., 2012, SOARES et al., 1999). These data indicate the need for better monitoring of Brazilian Lyme-Like disease or Baggio-Yoshinari Syndrome in different regions of Brazil.

In the Parana state few studies have sought the presence of anti-Borrelia antibodies in dogs (NASCIMENTO, 2012; VIEIRA et al., 2013). In the northern region of the Parana state, Vieira et al. (2013) used a commercial ELISA rapid test to detect the presence of anti-Borrelia spp. antibodies in dogs of urban and rural areas, but did not detected any positive samples. Differently, Nascimento (2012) used IFI to detect the presence of anti-Borrelia spp. antibodies in dog from rural settlement and detected $26.50 \%$ positive samples.

According to the CDC, WB is the gold standard technique to confirm an infection caused by Borrelia spp. In this study, the WB was able to confirm the presence of Lyme Borreliosis in 54 (32.14\%) dogs. This high prevalence may indicate the circulation of the etiologic agent in the northwestern region of Paraná state (MEAD et al., 2011; SMITH et al., 2012).

Mead et al. (2011) reported that a canine seroprevalence more than $5 \%$ is a sensitive but nonspecific marker of human risk, whereas seroprevalence lower or equal to $1 \%$ was associated with a minimal risk for human infection. Besides these data, for transmission of Borrelia spp., the presence of tick vectors is a prerequisite and the disease risk increases with tick abundance in the environment. The ticks are relatively more abundant in woodland, heath and moorland habitats, but can be found even in urban areas like parks, where hosts are plentiful. Few studies have reported the presence of ticks in urban areas, but some authors have suggested that the abundance and distribution of ticks in urban areas has increased (PIETZSCH et al., 2005). The presence of ticks in all dogs of this study reinforces the risk of transmission of Brazilian Lyme-Like disease or Baggio-Yoshinari Syndrome agents to humans in the studied area. Furthermore, Gonçalves et al. (2013b) detected B. burgdorferi s.1. DNA in ticks of Dermacentor nitens specie in the northern region of the Parana state.

The presence of B. burgdorferi s.l. in humans was also studied in the northwest region of Parana state. Using WB technique, Gonçalves et al. (2013a) detected the presence of anti-B. burgdorferi s.l. antibodies in two human serum samples. In these two cases, the presence of ticks inside homes, attached to the body and/or infesting dogs was observed. 
The results found in this study show the need for additional regional studies in humans, including the handlers of the shelter, as well as in the ticks from the stray dogs, in addition, new serological and molecular studies in different species of domestic animals and ticks in the study area are essential to the knowledge of the epidemiological characteristics of the etiologic agent in the northwest region of the state of Paraná.

\section{Acknowledgments}

The technical support of Laboratory of Leptospirosis and Lyme Borreliosis, Medical Microbiology Unit, Institute of Hygiene and Tropical Medicine (IHMT) from the Universidade Nova de Lisboa (UNL), Portugal; and Universidade Paranaense (UNIPAR) and CAPES (Coordenação de Aperfeiçoamento de Pessoal de Nível Superior) for the financial support.

\section{References}

ABEL, I. S.; MARZAGAO, G.; YOSHINARI, N. H.; SCHUMAKER, T. T. Borrelia-like spirochetes recovered from ticks and small mammals collected in the Atlantic Forest Reserve, Cotia county, State of Sao Paulo, Brazil. Memórias do Instituto Oswaldo Cruz, Rio de Janeiro, v. 95, n. 5, p. 621-624, 2000.

ALVES, A. D. L.; MADUREIRA, R. C.; SILVA, R. A. D.; CORRÊA, F. D. N.; BOTTEON, R. C. C. M. Frequência de anticorpos contra Borrelia burgdorferi em cães na região metropolitana do Rio de Janeiro. Pesquisa Veterinária Brasileira, Seropédica, v. 24, n. 4, p. 203206, 2004.

ARAGÃO, H. B.; FONSECA, F. Notas de Ixodologia, VIII. Lista e chave para os representantes da fauna ixodológica brasileira. Memórias do Instituto Oswaldo Cruz, Rio de Janeiro, v. 59, p. 115-129, 1961.

BARROS-BATTESTI, D. M.; YOSHINARI, N. H.; BONOLDI, V. L.; CASTRO GOMES, A. de. Parasitism by Ixodes didelphidis and I. loricatus (Acari: Ixodidae) on small wild mammals from an Atlatic Forest in the State of Sao Paulo, Brazil. Journal of Medical Entomology, Annapolis, v. 37, n. 6, p. 820-827, 2000.
BURGESS, E. C. Natural exposure of Wisconsin dogs to the lyme disease spirochete (Borrelia burgdorferi). Laboratory Animal Science, Memphis, v. 36, n. 3, p. 288290, 1986.

CARRANZA-TAMAYO, C. O.; COSTA, J. N.; BASTOS, W. M. Lyme disease in the state of Tocantins, Brazil: report of the first cases. Brazilian Journal of Infectious Diseases, Salvador, v. 16, n. 6, p. 586-589, 2012.

COLLARES-PEREIRA, M.; SANTOS, S. C.; VIEIRA, M. L. Valor diagnóstico da técnica de imunofluorescência indireta com diferentes estirpes no rastreio da Borreliose de Lyme. Trabalhos da Sociedade Portuguesa de Dermatologia e Venereologia, Lisboa, v. 58, p. 97-105, 2000.

CORDEIRO, M.; MEIRELES, G. J. S.; SOUZA, M.; FONSECA, A. H. Soroprevalência para Borrelia spp. em cães no município de Seropédica, estado do Rio de Janeiro. Revista Brasileira de Medicina Veterinária, Rio de Janeiro, v. 34, n. 3, p. 251-256, 2012.

CORREA, F. N.; TEIXEIRA, R. C.; OLIVEIRA, C. M.; BARBOSA, J. D.; FONSECA, A. H. da. Detection of anti-Borrelia burgdorferi antibodies in buffaloes (Bubalus bubalis) in the state of Para, Brazil. Revista Brasileira de Parasitologia Veterinária, Jaboticabal, v. 21, n. 3, p. 338-341, 2012.

DANTAS-TORRES, F. Canine vector-borne diseases in Brazil. Parasites \& Vectors, London, v. 1, n. 25, p. 25, 2008.

GONÇALVES, D. D.; BENITEZ, A.; LOPES-MORI, F. M.; ALVES, L. A.; FREIRE, R. L. Zoonoses in humans from small rural properties in Jataizinho, Parana, Brazil. Brazilian Journal of Microbiology, São Paulo, v. 44, n. 1, p. 125-131, 2013a.

GONÇALVES, D. D.; CARREIRA, T.; NUNES, M.; BENITEZ, A.; LOPES-MORI, F. M. First record of Borrelia burgdorferi B31 strain in Dermacentor nitens ticks in the northern region of Parana (Brazil). Brazilian Journal of Microbiology, São Paulo, v. 44, n. 3, p. 883$887,2013 b$.

JOPPERT, A. M.; HAGIWARA, M. K.; YOSHINARI, N. H. Borrelia burgdorferi antibodies in dogs from Cotia county, Sao Paulo State, Brazil. Revista Instituto de Medicina Tropical de São Paulo, São Paulo, v. 43, n. 5, p. 251-255, 2001.

LITTMAN, M. P.; GOLDSTEIN, R. E.; LABATO, M. A.; LAPPIN, M. R.; MOORE, G. E. ACVIM. Small animal consensus statement on Lyme disease in dogs: diagnosis, treatment, and prevention. Journal of Veterinary Internal Medicne, Malden, v. 20, n. 2, p. 422-434, 2006. 
MANTOVANI, E.; COSTA, I. P.; GAUDITANO, G.; BONOLDI, V. L.; HIGUCHI, M. L. Description of Lyme disease-like syndrome in Brazil. Is it a new tick borne disease or Lyme disease variation? Brazilian Journal of Medical and Biological Research, Ribeirão Preto, v. 40, n. 4, p. 443-456, 2007.

MANTOVANI, E.; MARANGONI, R. G.; GAUDITANO, G.; BONOLDI, V. I. N.; YOSHINARI, N. H. Amplification of the $f g E$ gene provides evidence for the existence of a Brazilian borreliosis. Revista do Instituto de Medicina Tropical de São Paulo, São Paulo, v. 54, n. 3, p. 153-158, 2012.

MEAD, P.; GOE, L. R.; KUGELER, K. Canine serology as adjunct to human Lyme disease surveillance. Emerging Infectious Diseases, Atlanta, v. 17, n. 9, p. 1710-1712, 2011.

MERINO, F. J.; SERRANO, J. L.; SAZ, J. V.; NEBREDA, T.; GEGUNDEZ, M. Epidemiological characteristics of dogs with Lyme borreliosis in the province of Soria (Spain). European Journal of Epidemiology, Berlin, v. 16, n. 2, p. 97-100, 2000.

NASCIMENTO, D. A. G. Prevalência de anticorpos anti-Borrelia spp. em humanos, cães e equinos de assentamento rural da região norte do Paraná. 2012. Dissertação (Mestrado em Ciência Animal) Universidade Estadual de Londrina, Londrina.

O'DWYER, L. H.; SOARES, C. O.; MASSARD, C. L.; SOUZA, J. C. P.; FLAUSINO, W.; FONSECA, A. H. Soroprevalência de Borrelia burgdorferi latu sensu associada a presença de carrapatos em cães de áreas rurais do Estado do Rio de Janeiro, Brasil. Ciência Rural, Santa Maria, v. 34, n. 1, p. 201-201, 2004.

PIETZSCH, M. E.; MEDLOCK, J. M.; JONES, L.; AVENELL, D.; ABBOTT, J. Distribution of Ixodes ricinus in the British Isles: investigation of historical records. Medical and Veterinary Entomology, San Diego, v. 19, n. 3, p. 306-314, 2005.
SMITH, F. D.; BALLANTYNE, R.; MORGAN, E. R.; WALL, R. Estimating Lyme disease risk using pet dogs as sentinels. Comparative Immunology, Microbiology and Infectious Diseases, New York, v. 35, n. 2, p. 163167, 2012.

SOARES, C. O.; FONSECA, A. H.; ISHIKAWA, M. M.; MANERA, G. B.; SCOFIELD, A. Sorologia para borreliose em cães procedentes da Baixada Fluminense, estado do Rio de Janeiro. Revista Brasileira de Medicina Veterinária, Rio de Janeiro, v. 21, p. 11-114, 1999.

SOARES, C. O.; ISHIKAWA, M. M.; FONSECA, A. H.; YOSHINARI, N. H. Borrelioses, agentes e vetores. Pesquisa Veterinária Brasileira, Rio de Janeiro, v. 20, n. 1, p. 1-19, 2000.

STEERE, A. C. Diagnosis and treatment of Lyme arthritis. Medical Clinics of North America, Philadelphia ,v. 81, n. 1, p. 179-194, 1997.

VIEIRA, T. S.; VIEIRA, R. F.; NASCIMENTO, D. A.; TAMEKUNI, K.; TOLEDO, R. Serosurvey of tickborne pathogens in dogs from urban and rural areas from Parana State, Brazil. Revista Brasileira de Parasitologia Veterinária, Jaboticabal, v. 22, n. 1, p. 104-109, 2013.

YOSHINARI, N. H.; ABRAO, M. G.; BONOLDI, V. L.; SOARES, C. O.; MADRUGA, C. R. Coexistence of antibodies to tick-borne agents of babesiosis and Lyme borreliosis in patients from Cotia county, State of Sao Paulo, Brazil. Memórias do Instituto Oswaldo Cruz, Rio de Janeiro, v. 98, n. 3, p. 311-318, 2003.

YOSHINARI, N. H.; MANTOVANI, E.; BONOLDI, V. L. N.; MARANGONI, R. G.; GAUDITANO, G. Brazilian lyme-like disease or Baggio-Yoshinari syndrome: exotic and emerging Brazilian tick-borne zoonosis. Revista da Associação Médica Brasileira, São Paulo, v. 56, n. 3, p. 363-9, 2010.

YPARRAGUIRRE, L. A.; MACHADO-FERREIRA, E.; ULLMANN, A. J.; PIESMAN, J.; ZEIDNER, N. S. A hard tick relapsing fever group spirochete in a Brazilian Rhipicephalus (Boophilus) microplus. Vector Borne and Zoonotic Diseases, New Rochelle, v. 7, n. 4, p. 717-721, 2007. 
